\title{
SISTEM PAKAR UNTUK ORANG TUA DALAM MENGETAHUI GAYA BELAJAR ANAK SESUAI TAHAP PERKEMBANGAN
}

\author{
Ria Wulandari ${ }^{1}$ \\ Padeli $^{2}$ \\ Rizki Maulana Kamil ${ }^{3}$
}

\begin{abstract}
Dosen STMIK Raharja ${ }^{1}$, Dosen AMIK Raharja Informatika ${ }^{2}$, Mahasiswa STMIK Raharja ${ }^{3}$ e-mail: $\underline{\text { wulandari@ raharja.info }}{ }^{1}$, padeli@ raharja.info $^{2}$, rizki.maulana@ raharja.info ${ }^{3}$
\end{abstract}

\begin{abstract}
ABSTRAKSI
Era teknologi internet of thing terkini menuntut para orang tua untuk bisa mengikuti perkembangan anak dan juga jaman, dikarenakan sejak jaman dahulu di Indonesia banyak para orang tua tidak mengetahui dan menyadari pola gaya belajar yang tepat pada saat itu. Untuk mengenal karakter anak melalui gaya belajar, orang tua wajib mengenal gaya belajar anak. Adapun jenis-jenis dari gaya belajar pada anak yaitu visual, auditory dan kinestetik. Setiap gaya belajar memiliki ciri-ciri tertentu, hal ini wajib diketahui orang tua dengan serangkaian pertanyaan. Penelitingnya pengetahuan tentang gaya belajar anak ini masih sedikit dari para orang tua yang mengenal hal ini. Hal ini menjadi permasalahan terbesar yang dialami bangsa ini dan penting untuk diketahui oleh para orang tua dalam mengenal karakter anak mengetahui gaya belajar anak. Ada pepatah mengatakan "Tak kenal maka tak peneliting", kenali anak melalui pola gaya belajar sebagai modal hingga besarnya nanti. Metode analisa yang digunakan pada sistem pakar ini adalah metode forward chaining dan pohon keputusan sebagai landasan dari sistem pakar. Perancangan model sistem menggunakan UML (Unified Modelling Language), implementasi menggunakan bahasa PHP dan MySQL. Manfaat dari sistem ini dibangun untuk menciptakan orang tua yang mengenal karakter gaya belajar anak dikarenakan kemampuan mereka menyerap dan beradaptasi di era disruptive.
\end{abstract}

Kata Kunci: Gaya Belajar, Visual, Auditorial, Kinestetik, VAK

\section{ABSTRACT}

In the current era of internet of thing technology requires parents to be able to keep up with the development of children and also times, because since ancient times in Indonesia many parents did not know and were aware of the right learning style patterns at that time. To get to know the character of the child through learning styles, parents must recognize the child's learning style. The types of learning styles in children are visual, auditory and kinesthetic. Every learning style has certain characteristics, this must be known to parents by a series of questions. Unfortunately, knowledge of this child's learning style is still very little from parents who know this. This has become the biggest problem experienced by this nation and it is important to be known by parents in recognizing the character of children knowing their children's learning style. There is a saying, "Do not know then no love", recognize the child through the pattern of learning styles as capital until later. The analytical method used in this expert system is the forward chaining method and decision tree as the basis of the expert system. Designing a system model using UML (Unified Modeling Language), implementation using PHP and MySQL languages. The benefits of this system are built to create parents who are familiar with the character of children's learning styles because of their ability to absorb and adapt in the disruptive era.

Keywords: Learning Style, Gaya Visual, Auditorial, Kinestetik, VAK 


\section{PENDAHULUAN}

\section{Latar Belakang}

Pada era globalisasi saat ini, teknologi semakin berkembang dengan sangat canggih. Komputer sangat berperan penting dalam perkembangan teknologi ini. Dengan segala kelebihannya, komputer telah menjadi bagian utama yang sangat diperlukan untuk membantu manusia dalam mengerjakan tugas dan menyelesaikan masalah. Sistem pakar merupakan salah satu bidang teknik kecerdasan buatan yang cukup diminati karena penerapannya diberbagai bidang baik bidang ilmu pengetahuan maupun bisnis yang terbukti sangat membantu dalam mengambil keputusan dan sangat luas penerapanya. Sistem pakar merupakan suatu sistem komputer yang dirancang agar dapat melakukan penalaran seperti layaknya seorang pakar pada suatu bidang keahlian tertentu. Sistem pakar diciptakan bukan untuk menggantikan kedudukan seorang pakar tetapi untuk memasyaratkan pengetahuan dan pengalaman pakar tersebut untuk orang banyak.

Proses gaya belajar anak penting dikenali oleh orang tua, sehingga memudahkan mereka para orang tua untuk memberikan pengajaran yang baik. Di Indonesia sendiri banyak orang tua tidak mengenali gaya belajar anak masing-masing. Hal ini disebabkan beberapa faktor yang mempengaruhi ketidaktahuan tersebut. Dibutuhkan hubungan yang menjadi jembatan antar orang tua dan anak untuk mengetahui karakter gaya belajar mereka sehingga memotivasi sang anak dengan efektif. Ilmu psikologi merupakan ilmu pengetahuan yang mempelajari perilaku manusia dan mental. Melihat hal tersebut sangat mungkin ilmu pengetahuan dikembangkan dalam memanfaatkan teknologi untuk ikut terlibat didalamnya. Pada prakteknya, ilmu psikologi sebagian besar masih metode konvesional dalam proses memahami dan mempelajari sisi psikologi suatu objek. Objek yang dimaksud disini adalah manusia dengan segala sikap dan tingkah lakunya. Salah satu metode yang masih banyak digunakan dalam ilmu psikologi yakni dengan cara membuat lembaran kuisioner yang akan diberikan kepada objek.

Disadari atau tidak disadari dunia pendidikan pada saat ini khususnya di Indonesia mengalami masalah antara lain menurunnya kualitas pendidikan dan mutu pendidikan yang masih rendah. Oleh karena itu menurunnya kualitas pendidikan merupakan tanggung jawab kita bersama terutama oleh orang tua. Untuk mencapai tujuan pendidikan yang baik orang tua harus ada sebagai landasan awal anak selain di sekolah. Pola asuh pun memungkinkan terbentuknya faktor gaya belajar anak, minat belajar, minat membaca, motivasi diri, dan kecerdasan. Dalam penulisan ini peneliti akan mengkaji hubungan dua faktor kualitas pendidikan seorang anak yaitu gaya belajar dan tahap perkembangan.

\section{RUMUSAN MASALAH}

Melihat paparan diatas dapat ditarik rumusan permasalahan terkait dengan bagaimana bentuk kaya belajar siswa yang ada saat ini, kemudian pertanyaan apakah gaya belajar siswa di sekolah yang saat ini ada sudah berjalan secara efektif dan efisien, serta pertanyaan tentang bagaimana merancang sistem pakar untuk menentukan gaya belajar siswa.

\section{METODE PENELITIAN}

Metode penelitian merupakan suatu tata cara atau kegiatan pelaksanaan penelitian rangka untuk mengumpulkan informasi atau data serta melakukan investigasi terhadap data yang telah didapatkan tersebut. yang didasari oleh asumsi-asumsi dasar, pandangan-pandangan filosofis dan ideologis, pertanyaan dan isu-isu yang dihadapi. Suatu penelitian mempunyai rancangan penelitian tertentu. Rancangan ini menggambarkan prosedur atau langkah-langkah yang harus ditempuh, waktu penelitian, sumber data dan kondisi arti untuk apa data dikumpulkan dan dengan cara bagaimana data tersebut dihimpun dan diolah untuk dianalisa dalam pembuatan laporan. 
1. Metode Observasi (Observation Research)

Pada tahapan ini penulis melakukan pengamatan langsung dari objek penelitian untuk mendapatkan data dan informasi yang akurat dan lengkap dari berbagai pihak yang terkait dan berhubungan dengan tema penelitian yang berhasil penulis rumuskan

\section{a. Metode Wawancara (Interview Research)}

Metode yang dilakukan penulis untuk mendapatkan data dengan cara wawancara atau tanya jawab secara lisan baik itu kepada stake holder terkait untuk mendapatkan data yang diperlukan.

\section{b. Metode Studi Pustaka (Study Literature)}

Selain melakukan observasi penulis juga melakukan pendataan dengan cara studi pustaka dengan cara berusaha untuk melengkapi data-data yang diperoleh dengan membaca dan mempelajari dari buku-buku dan data-data yang relevan dalam pemilihan judul yang penulis ajukan. Buku dan data tersebut digunakan penulis untuk membantu penganalisaan dan perancangan yang dilakukan.

\section{c. Metode Studi Kuisioner}

Metode yang berisi daftar pertanyaan yang ditujukan kepada responden. Jawaban responden atas semua pertanyaan dalam kuisioner kemudian dicatat/direkam. Tentunya pertanyaan berkaitan erat dengan karakter anak didalam keseharian sehingga mendapatkan jawaban tepat, sesuai kebutuhan gaya belajar untuk anak melalui orang tua.

\section{Metode Analisis Data}

Pada penelitian ini, metode analisa dilakukan dengan langkah-langkah melakukan pengamatan dan analisa terhadap sistem yang berjalan saat ini, serta menentukan UML (Unified Modeling Language) yang meliputi use case diagram, activity diagram, sequence diagram.

\section{PEMBAHASAN}

Untuk dapat menggambarkan prosedur secara keseluruhan diperlukan bebrapa tahapan analisa sebagai bentuk pengumpulan informasi guna mendapatkan model yang sesuai dengan kebutuhan dan mampu memberikan solusi dengan cepat secara efektif dan efisien, mulai dari tahapan pengumpulan informasi dan kebutuhan, analisa dokumen, merancangan hubungan antar dokumen sampai dengan merancanga model diagram database dan model rancangan sistem. Beberapa tahapan yang dimaksud sampai dengan model ranangan yang diciptakan dapat dilihat pada gambar 1,2,3,4,5.

\section{Use Case Diagram Prosedur Berjalan}

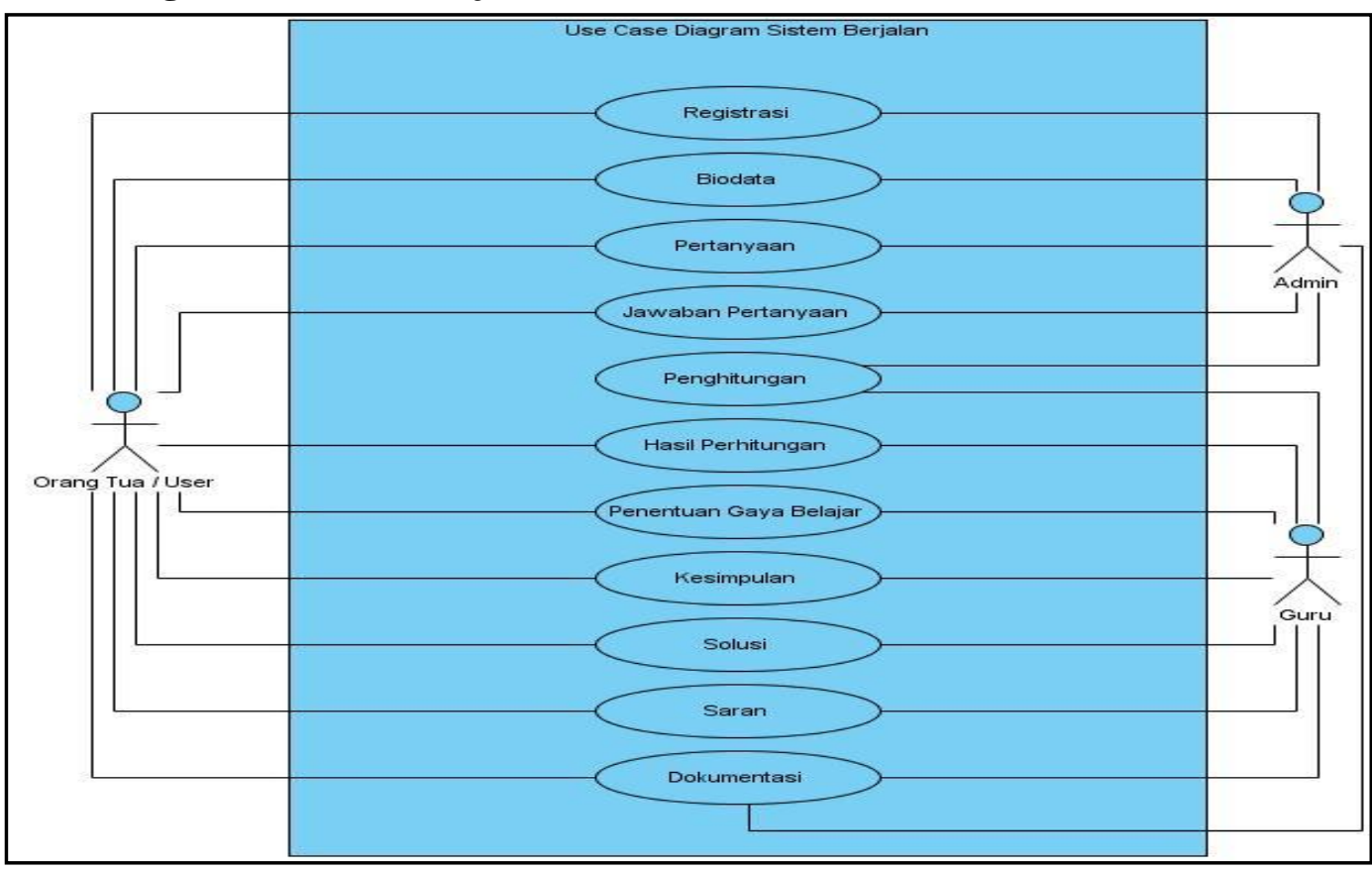

Gambar 1. Use Case Diagram 
Berdasarkan gambar Use Case Diagram (gambar 1) yang berjalan saat ini sistem yang mencakup seluruh kegiatan pada sistem prosedur mengetahui gaya belajar. Terdapat 3 (tiga) aktor yang melakukan kegiatan yaitu admin yang bertugas menangani registrasi, biodata, pertanyaan, jawaban pertanyaan, penghitungan dan juga dokumentasi. Juga ada aktor user/orang tua dan guru dengan lingkup kegiatan yang bisa dilakukan sesuai gambar use case.

Terdapat juga 11 (sebelas) use case yang merupakan proses terjadinya pada prosedur sistem yang berjalan yaitu registrasi yang bisa dilakukan oleh user dan admin merupakan tahap awal dari proses untuk mengetahui gaya belajar, selain itu ada menu pertanyaan yang wajib diisi oleh user dimana hal ini merupakan tahap wajib diisi oleh orang tua, setelah itu orang tua menunggu hasil yang diberikan oleh guru disana berisi use case penentuan gaya belajar, kesimpulan, solusi dan saran. Selanjutnya di dokumentasikan oleh guru dan di arsip oleh admin diteruskan hasil dokumentasi tersebut kepada orang tua.

2. Activity Diagram Prosedur Berjalan

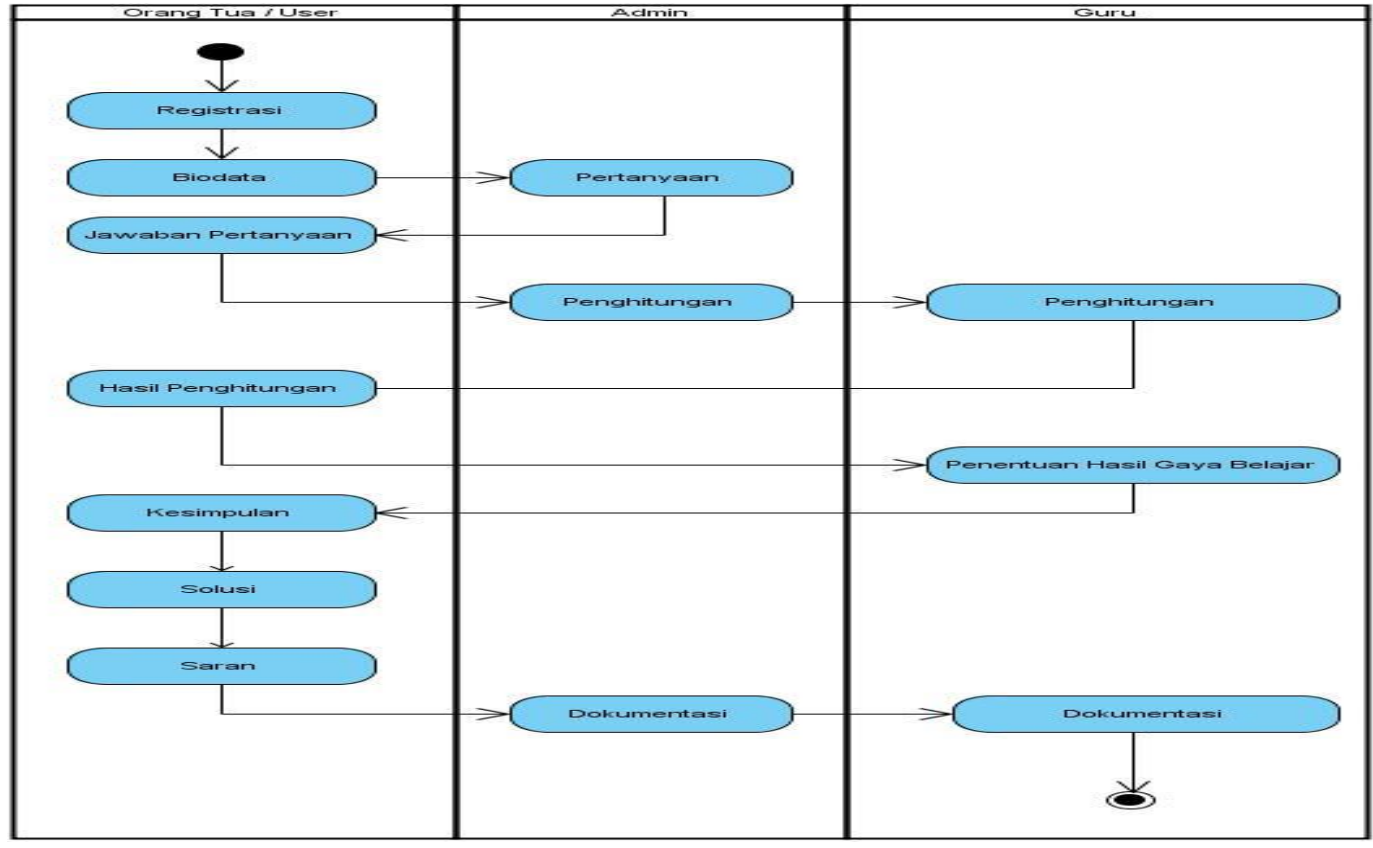

Gambar 2. Activity Diagram

Berdasarkan gambar Activity Diagram (gambar 2) yang berjalan saat ini, sistem mencakup seluruh kegiatan prosedur mengetahui gaya belajar untuk orang tua. Sistem ini melibatkan 3 (tiga) aktor yaitu, user yang mengisi rangkaian registrasi dan biodata, kemudian diberikan pertanyaan oleh admin yang harus diisi oleh user, kemudian dihitung hasilnya oleh admin melalui guru sehingga menghasilkan dokumentasi yang berupa kesimpulan solusi dan saran untuk orang tua.

\section{Sequence Diagram Prosedur Berjalan}

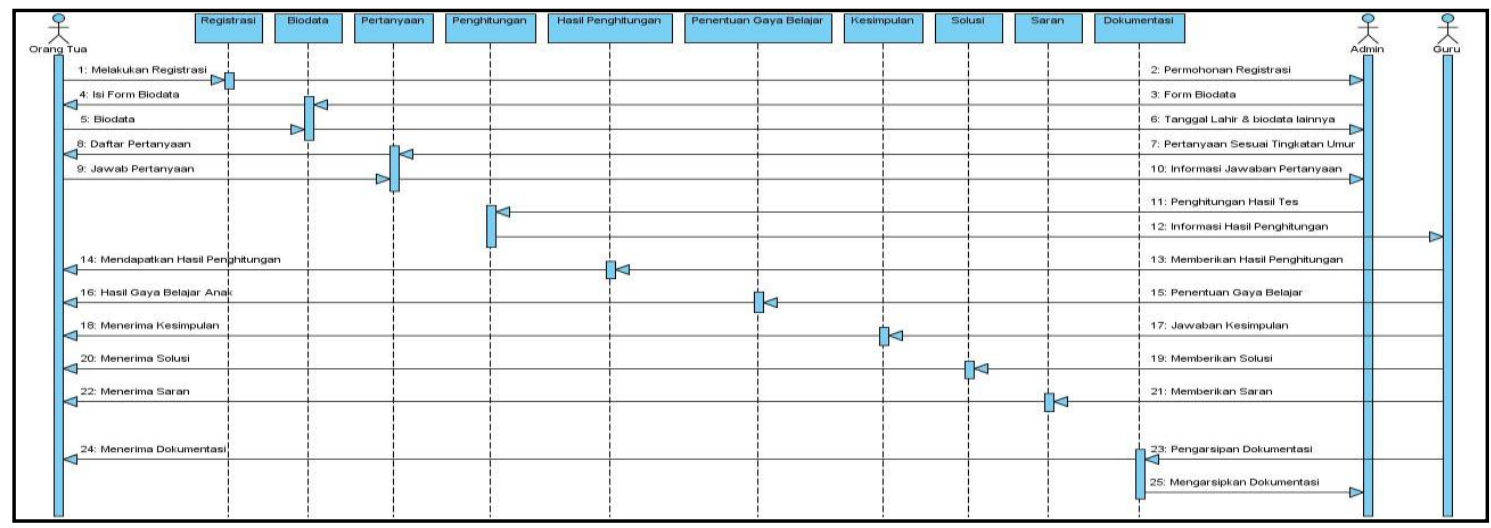

Gambar 3. Sequence Diagram 
Berdasarkan sequence diagram (gambar 3) yang berjalan saat ini terlihat 3 (tiga) aktor yang melakukan kegiatan diantaranya: user, admin dan guru, yang akan menyelesaikan tahapan prosedur kegiatan mengetahui gaya belajar yang memuat informasi-informasi yang dibutuhkan oleh user dan didokumentasi oleh guru yang kemudia diarsipkan oleh admin.

Rancangan diatas (gambar 1,2,3) merupakan gambaran prosedur yang berjalan dimana pada tahapan ini melibatkan beberapa proses dari mulai registrasi hingga sampai tahap dokumentasi dan dijabarkan pada gambar 3 (tiga) semua tahapan-tahapan lengkap yang dibutuhkan. Semua proses melibatkan ketiga aktor, pertanyaan adalah tahap dimana user mengisi semua pilihan jawaban yang diberikan admin pertanyaannya berdasarkan ciri-ciri karakter gaya belajar dibentuk dengan suatu kondisi tertentu pada anak saat di tempat umum ataupun yang sering dilhat oleh orang tua, kemudian orang tua mengisi jawaban sesuai dengan karakter anak masing-masing sesuai pilihan jawaban yang sudah ada. Sedangkan Peran guru sebagai pemberi hasil jawaban, kesimpulan, saran dan solusi untuk diketahui oleh orang tua sebagai user atau aktor utamanya.

\section{Class Diagram}

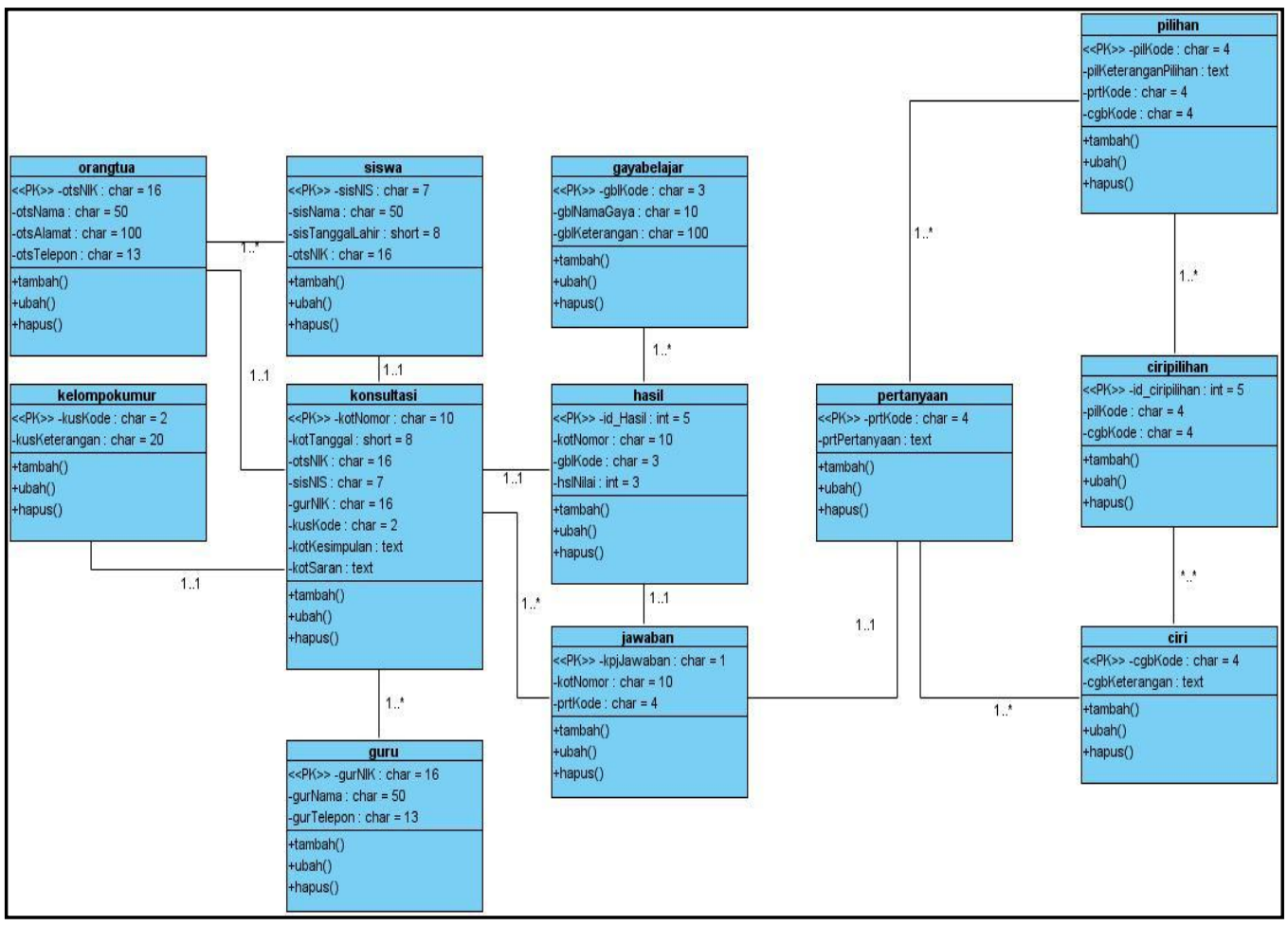

Gambar 4. Class Diagram

Berdasarkan gambar class diagram (gambar 4) yang berjalan saat ini system yang mencakuo seluruh kegiatan pada sistem prosedur mengetahui gaya belajar. Terdapat 12 (dua belas) class dengan penambahan yang berada di class diagram yaitu menu class konsultasi yang berperan dalam tindakan pengambilan keputusan sang pakar, terciptanya semua hubungan pada sistem pakar ini terhubung dengan pangkalnya yaitu menu class konsultasi.

Dapat dilihat dengan jelas bahwa tingkat hubungan konsultasi dan guru yaitu one to many $(1: \mathrm{M})$, tingkat hubungan gayabelajar dan hasil adalah one to many (1:M), tingkat hubungan pilihan dengan pertanyaan dan ciripilihan adalah one to many (1:M), tingkat hubungan ciripilihan dan ciri adalah may to many (M:M), tingkat hubungan ciri dan pertanyaan adalah one to many $(1: \mathrm{M})$, tingkat hubungan antara jawaban dan hasil adalah one to one (1:1). Semua menu class diagram ini bertujuan untuk mencapai kompleksitas dari suatu sistem yang dibangun. 


\section{Use Case Diagram Usulan}

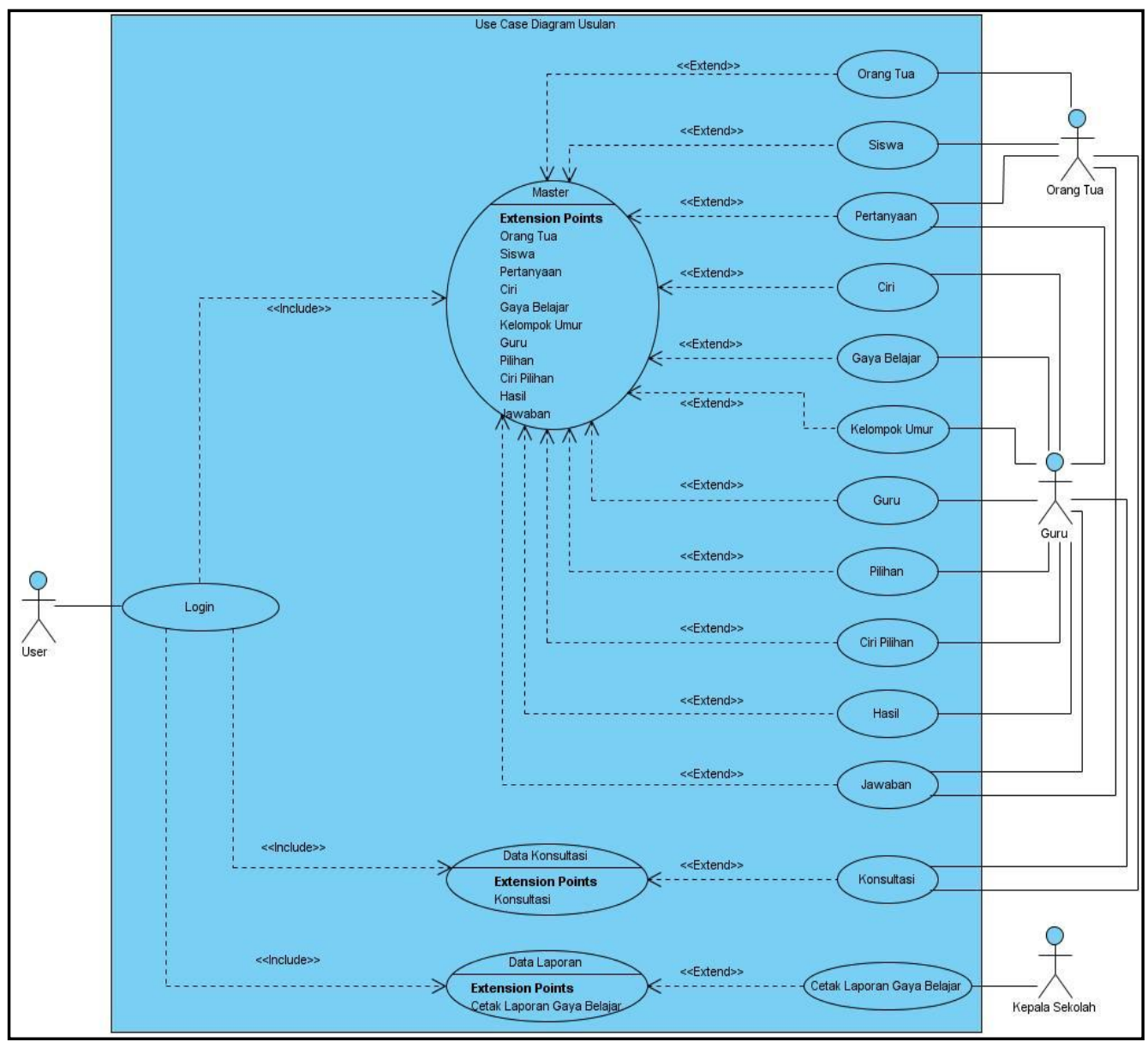

Gambar 5. Use Case Diagram Usulan

Berdasarkan gambar use case diagram usulan (gambar 5) terlihat jelas bahwa terdapat 17 (tujuh belas) use case yang terdiri dari 3 (tiga) use case utama yaitu master, data konsultasi dan data laporan. Use case master terdiri dari perpanjangan dari (12) dua belas use case sebelumnya yang berada di class diagram. Use case data konsultasi terdiri hanya 1 (satu) perpanjangan yaitu menu konsultasi. Use case data laporan pu hanya memiliki satu perpanjangan yaitu menu cetak laporan gaya belajar. Kemudian ada menu login yang bertugas untuk memasuki semua rangkaian alur sistem selanjutnya logout untuk keluar dari sistem.

Use case diagram sebagai bentuk rancangan sistem yang akan diciptakan (gambar 5) dan merupakan desain model tampilan utama yang berorientasi pada kebutuhan menu pada aplikasi yang sedang dirancang, selain itu untuk kebutuhan penyimpanan informasi data agar dapat digunakan oleh orang tua, user, guru dan kepala sekolah dengan mudah, juga sebagai histori basis data sistem yang akan disimpan oleh sistem, digambarkan dalam bentuk class diagram (gambar 4) lengkap dengan informasi field dan type data sesuai kebutuhan penyimpanan data.

\section{IMPLEMENTASI}

\section{Rancangan Basis Data}

Untuk dapat menggambarkan bentuk basis data secara utuh, peneliti menggunakan localhost/phpmyadmin lalu masuk kedalam query untuk lalu di ambil gambar sebagai bentuk gambaran dasar, dan pada akhirnya bentuk rancangan basis data ini dapar disesuaikan menggunakan apa saja sesuai kebutuhan.
a. Table Admin
Primary Key : id_admin 
Foreign Key : -

Structure Table : $\{$ id_admin, nama, username, password, id_level, foto $\}$

Tabel 1. Struktur Admin

\begin{tabular}{|c|c|c|c|c|c|c|c|c|}
\hline & $\#$ & Name & Type & Collation & Attributes & Null & Default & Extra \\
\hline$\square$ & 1 & id_admin & int(2) & & & No & None & AUTO_INCREMENT \\
\hline$\square$ & 2 & nama & $\operatorname{varchar}(40)$ & & & No & None & \\
\hline$\square$ & 3 & username & varchar(15) & & & No & None & \\
\hline$\square$ & 4 & password & $\operatorname{varchar}(10)$ & & & No & None & \\
\hline$\square$ & 5 & id_level & $\operatorname{int}(2)$ & & & No & None & \\
\hline$\square$ & 6 & foto & $\operatorname{varchar}(50)$ & & & No & None & \\
\hline
\end{tabular}

\section{b. Tabel Ciri}

Primary Key : cgbKode

Foreign Key : id

Structure Table : $\{$ id, cgbKode, cgbKeterangan $\}$

Tabel 2. Struktur Ciri

\begin{tabular}{|lllllll|}
\hline$\#$ & Name & Type & Collation & Attributes & Null & Default Extra \\
\hline & 1 & id & int $(5)$ & No & None & AUTO_INCREMENT \\
$\square$ & 2 & cgbKode & char(4) & No & None \\
$\square$ & & cgbKeterangan text & No & None \\
\hline
\end{tabular}

\section{c. Tabel CiriPilihan}

Primary Key : id_ciripilihan

Foreign Key

Structure Table : $\{$ id_ciripilihan, pilKode, cgbKode $\}$

Tabel 3. Struktur CiriPilihan

\begin{tabular}{|lllllll|}
\hline \# & Name & Type & Collation & Attributes & Null & Default Extra \\
$\square$ & 1 & id_ciripilihan & int(5) & No & None \\
$\square$ & 2 & pilKode & char(4) & No & None \\
$\square$ & 3 & cgbKode & $c h a r(4)$ & No & None \\
\hline
\end{tabular}

\section{d. Tabel GayaBelajar}

Primary Key : gblKode

Foreign Key :

Structure Table : \{gblKode, gblNamaGaya, gblKeterangan\}

Tabel 4. Struktur GayaBelajar

\begin{tabular}{|lllllll|}
\hline \# & Name & Type & Collation & Attributes & Null Default Extra \\
$\square$ & 1 & gblKode & $\operatorname{char}(3)$ & No & None \\
$\square$ & 2 & gbINamaGaya & $\operatorname{char}(10)$ & No & None \\
$\square$ & 3 & gblKeterangan & $\operatorname{char}(100)$ & No & None \\
\hline
\end{tabular}


e. Tabel Guru

Primary Key : gurNIK

Foreign Key

Structure Table : \{gurNIK, gurNama, gurTelepon $\}$

Tabel 5. Struktur Guru

\begin{tabular}{|c|c|c|c|c|c|c|c|c|}
\hline & $\#$ & Name & Type & Collation & Attributes & Null & Default & Extra \\
\hline$\square$ & 1 & gurNIK & char(16) & & & No & None & \\
\hline$\square$ & 2 & gurNama & char $(50)$ & & & No & None & \\
\hline$\square$ & 3 & gurTelepon & char(13) & & & No & None & \\
\hline
\end{tabular}

f. Tabel Hasil

Primary Key : id_Hasil

Foreign Key :

Structure Table : \{id_Hasil, kotNomor, gblKode, hslNilai $\}$

Tabel 6. Struktur Hasil

\begin{tabular}{|c|c|c|c|c|c|c|c|}
\hline & \# & Name & Type & Collation & Attributes & Null & Default Extra \\
\hline$\square$ & 1 & id_Hasil $\gg$ & int (5) & & & No & None \\
\hline$\square$ & 2 & kotNomor & char(10) & & & No & None \\
\hline$\square$ & 3 & gblkode & char(3) & & & No & None \\
\hline$\square$ & 4 & hsINilai & int(3) & & & No & None \\
\hline
\end{tabular}

g. Tabel Jawaban

Primary Key : kpjJawaban

Foreign Key

Structure Table : \{kpjJawaban, kotNomor, prtKode $\}$

Tabel 7. Struktur Jawaban

\begin{tabular}{|lllllll|}
\hline & $\#$ & Name & Type & Collation Attributes & Null Default Extra \\
$\square$ & 1 & kpjJawaban & $\operatorname{char}(1)$ & No & None \\
$\square$ & 2 & kotNomor & $\operatorname{char}(10)$ & No & None \\
$\square$ & 3 & prtKode & $\operatorname{char}(4)$ & No & None \\
\hline
\end{tabular}

h. Tabel Kelompok_Umur

Primary Key : kusKode

Foreign Key :

Structure Table : \{kusKode, kusKeterangan\}

Tabel 8. Struktur Kelompok_Umur

\begin{tabular}{|c|c|c|c|c|c|c|}
\hline & $\#$ & Name & Type & Collation Attributes & Null & Default Extra \\
\hline$\square$ & 1 & kusKode & $\operatorname{char}(2)$ & & No & None \\
\hline$\square$ & 2 & kusKeterangan & $\operatorname{char}(50)$ & & No & None \\
\hline
\end{tabular}


i. Tabel Konsultasi

Primary Key : kotNomor

Foreign Key

Structure Table : \{kotNomor, kotTanggal, otsNIK, sisNIS, gurNIK, kusKode, kotKesimpulan, kotSaran\}

Tabel 9. Struktur Konsultasi

\begin{tabular}{|c|c|c|c|c|c|c|c|c|}
\hline & $\#$ & Name & Type & Collation & Attributes & Null & Default & Extra \\
\hline$\square$ & 1 & kotNomor & char(10) & & & No & None & \\
\hline$\square$ & 2 & kotTanggal & date & & & No & None & \\
\hline$\square$ & 3 & otsNIK & char(16) & & & No & None & \\
\hline$\square$ & 4 & sisNIS & char(7) & & & No & None & \\
\hline$\square$ & 5 & gurNIK & char(16) & & & No & None & \\
\hline$\square$ & 6 & kuskode & char(2) & & & No & None & \\
\hline$\square$ & 7 & kotKesimpulan & text & & & No & None & \\
\hline$\square$ & 8 & kotSaran & text & & & No & None & \\
\hline
\end{tabular}

\section{j. Tabel Orangtua}

Primary Key : otsNIK

Foreign Key

Structure Table : \{otsNIK, otsNama, otsAlamat, otsTelepon\}

Tabel 10. Struktur Orangtua

\begin{tabular}{|c|c|c|c|c|c|c|c|c|}
\hline & $\#$ & Name & Type & Collation & Attributes & Null & Default & Extra \\
\hline$\square$ & 1 & otsNIK 0 & char(16) & & & No & None & \\
\hline$\square$ & 2 & otsNama & char (50) & & & No & None & \\
\hline$\square$ & 3 & otsAlamat & char(100) & & & No & None & \\
\hline$\square$ & 4 & otsTelepon & char(13) & & & No & None & \\
\hline
\end{tabular}

\section{k. Tabel Pertanyaan}

Primary Key : prtKode

Foreign Key : id

Structure Table : $\{$ id, prtKode, prtPertanyaan $\}$

Tabel 11. Struktur Pertanyaan

\begin{tabular}{|llllllll|}
\hline \# & Name & Type & Collation & Attributes & Null & Default & Extra \\
$\square$ & 1 & id $P$ & int $(5)$ & No & None & AUTO_INCREMENT \\
$\square$ & 2 & prtKode & $\operatorname{char}(4)$ & No & None \\
$\square$ & 3 & prtPertanyaan text & No & None \\
\hline
\end{tabular}

\section{Tabel Pilihan}

Primary Key : pilKode

Foreign Key :

Structure Table : \{pilKode, pilKeteranganPilihan, prtKode, cgbKode $\}$

Tabel 12. Struktur Pilihan

\begin{tabular}{|c|c|c|c|c|c|c|c|c|}
\hline & \# & Name & Type & Collation & Attributes & Null & Default & Extra \\
\hline$\square$ & 1 & pilkode & char(4) & & & No & None & \\
\hline$\square$ & 2 & pilketeranganPilihan & text & & & No & None & \\
\hline$\square$ & 3 & prtKode & char(4) & & & No & None & \\
\hline$\square$ & 4 & cgbKode & char(4) & & & No & None & \\
\hline
\end{tabular}


m. Tabel Registrasi

Primary Key : id_register

Foreign Key

Structure Table : \{id_register, nama_depan, nama_belakang, no_ktp, email nama_anak1, nama_anak2, nama_anak3,...\}

Tabel 13. Struktur Registrasi

\begin{tabular}{|c|c|c|c|c|c|c|c|c|}
\hline & \# & Name & Type & Collation & Attributes & Null & Default & Extra \\
\hline$\square$ & 1 & id_register & $\operatorname{int}(5)$ & & & No & None & AUTO_INCREMENT \\
\hline$\square$ & 2 & nama_depan & varchar(30) & & & No & None & \\
\hline$\square$ & 3 & nama_belakang & varchar(30) & & & No & None & \\
\hline$\square$ & 4 & no_ktp & varchar(16) & & & No & None & \\
\hline$\square$ & 5 & email & varchar(50) & & & No & None & \\
\hline$\square$ & 6 & nama_anak1 & varchar(30) & & & No & Nane & \\
\hline$\square$ & 7 & nama_anak2 & $\operatorname{varchar}(30)$ & & & No & None & \\
\hline$\square$ & 8 & nama_anak3 & varchar(30) & & & No & None & \\
\hline$\square$ & 9 & nama_anak4 & varchar(30) & & & No & Nane & \\
\hline$\square$ & 10 & nama_anak5 & varchar(30) & & & No & None & \\
\hline$\square$ & 11 & nama_anak6 & varchar(30) & & & No & None & \\
\hline$\square$ & 12 & tanggal_lahir1 & date & & & No & None & \\
\hline$\square$ & 13 & tanggal_lahirz & date & & & No & None & \\
\hline$\square$ & 14 & tanggal_lahir3 & date & & & No & None & \\
\hline 70 & 15 & tanggal_lahir4 & date & & & No & Nane & \\
\hline$\square$ & 16 & tanggal_lahir5 & date & & & No & None & \\
\hline$\square$ & 17 & tanggal_lahir6 & date & & & No & None & \\
\hline$\square$ & 18 & nis1 & $\operatorname{varchar}(7)$ & & & No & None & \\
\hline$\square$ & 19 & nis2 & $\operatorname{varchar}(7)$ & & & No & None & \\
\hline$\square$ & 20 & nis3 & $\operatorname{varchar}(7)$ & & & No & None & \\
\hline$\square$ & 21 & nis4 & $\operatorname{varchar}(7)$ & & & No & None & \\
\hline$\square$ & 22 & nis5 & $\operatorname{varchar}(7)$ & & & No & None & \\
\hline$\square$ & 23 & nis6 & $\operatorname{varchar}(7)$ & & & No & None & \\
\hline$\square$ & 24 & password & varchar(20) & & & No & None & \\
\hline$\square$ & 25 & jenis_kelamin & varchar(10) & & & No & None & \\
\hline$\square$ & 26 & id_level & $\operatorname{int}(5)$ & & & No & None & \\
\hline
\end{tabular}

n. Tabel Siswa

Primary Key : sisNIS

Foreign Key :

Structure Table : \{sisNis, sisNama, sisTanggalLahir, otsNIK\}

Tabel 14. Struktur Siswa

\begin{tabular}{|c|c|c|c|c|c|c|c|c|}
\hline & \# & Name & Type & Collation & Attributes & NulI & Default & Extra \\
\hline$\square$ & 1 & sisNIS & char(7) & & & No & None & \\
\hline$\square$ & 2 & sisNama & char(50) & & & No & None & \\
\hline$\square$ & 3 & sisTanggallahir & date & & & No & None & \\
\hline$\square$ & 4 & otsNIK & char(16) & & & No & None & \\
\hline
\end{tabular}

2. Rancangan Layar

Berikut ini akan dijabarkan mengenai rancangan layar untuk sistem yang diusulkan:

a. Tampilan Menu Login

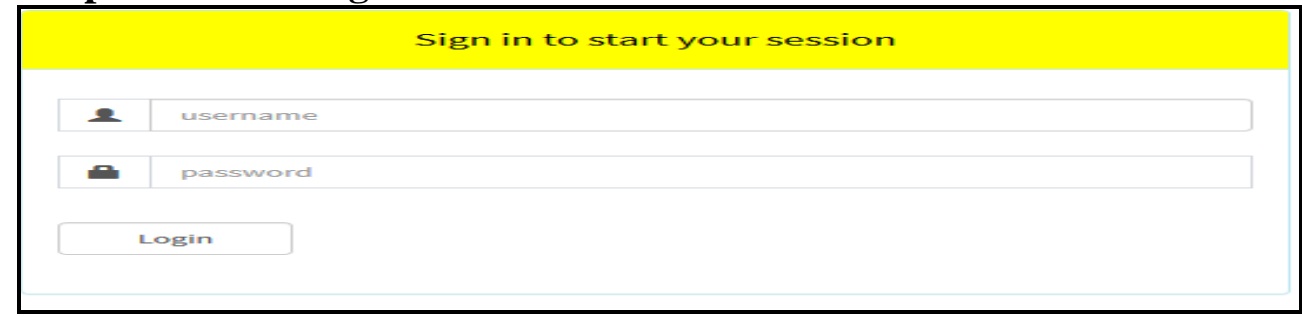

Gambar 6. Tampilan Login 


\section{b. Tampilan Menu Dashboard Admin}

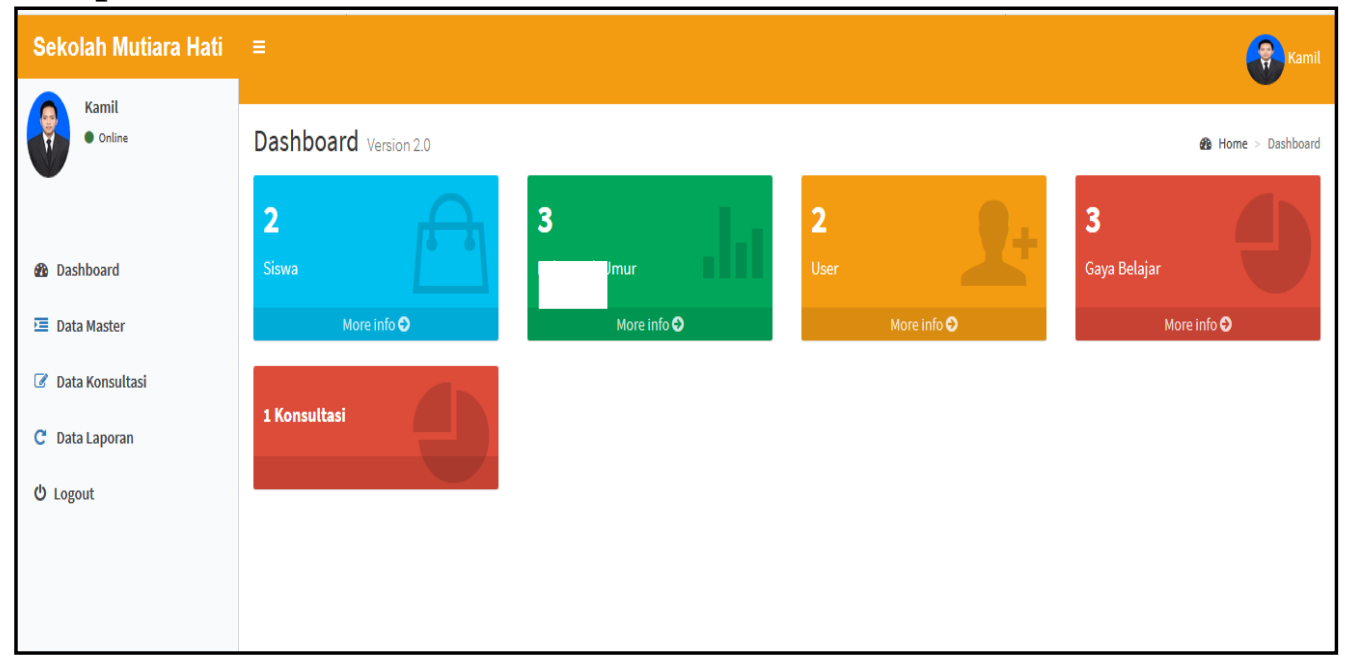

Gambar 7. Tampilan Menu Dashboard

\section{c. Tampilan Menu Data Master Admin}

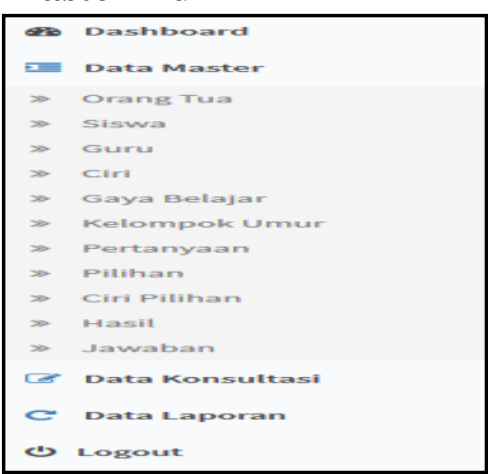

Gambar 8. Tampilan Data Master

\section{d. Tampilan Menu Pertanyaan}

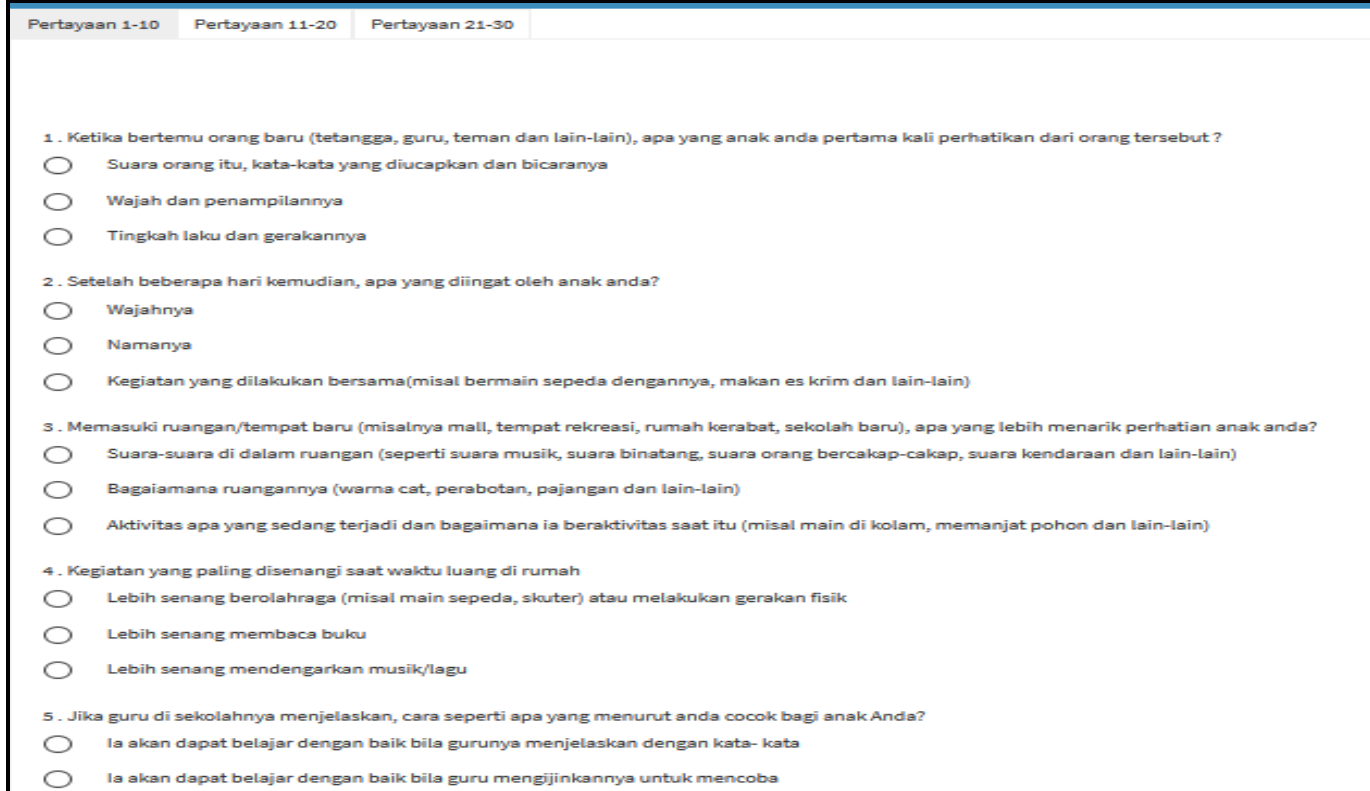

Gambar 9. Tampilan Pertanyaan Pilihan Kelompok Umur 


\section{e. Tampilan Menu Pertanyaan}

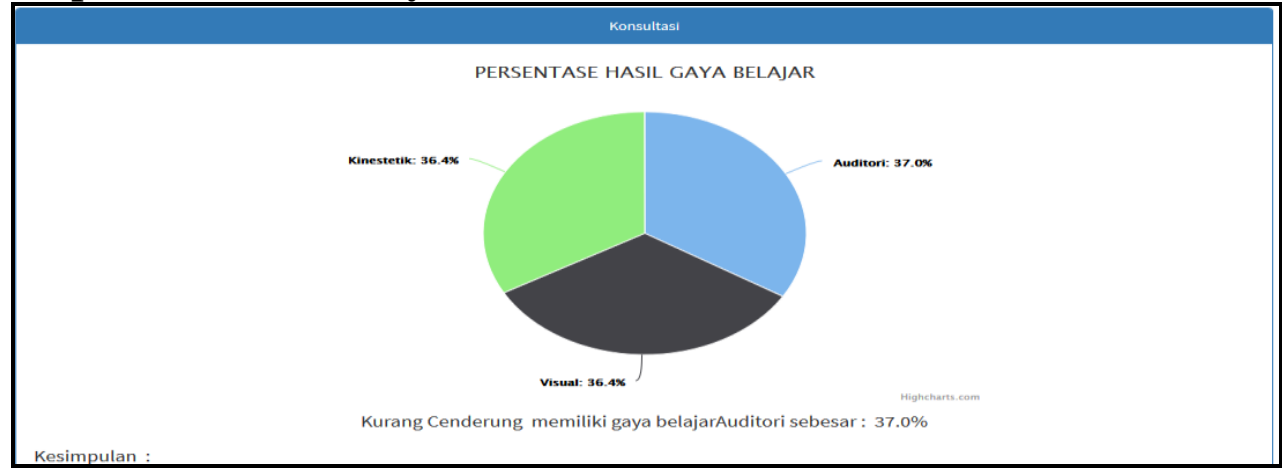

Gambar 10. Tampilan Pie Persentase Hasil Gaya Belajar

\section{DAFTAR PUSTAKA}

[1] Rijan, Yunirman, and Ira Koesoemawati. "Cara Mudah Membuat Surat Perjanjian/Kontrak dan Surat Penting Lainnya." Raih Asa Sukses, Depok (2009).

[2] Junaidi, Junaidi, Ladyca Anugrah, and Adhitya Dwi Pancasakti. "Model Aplikasi Monitoring Sistem Absensi Sidik Jari Sebagai Pendukung Keputusan Untuk Penilaian Kinerja Pegawai." Proceedings Konferensi Nasional Sistem dan Informatika (KNS\&I) (2015).

[3] Sugianto. 2013. "Perancangan Sistem Informasi Penjualan Pada Butik Luwes Fashion Kecamatan Tulakan." Indonesian Jurnal on Computer Science-Speed (IJCSS) Vol 2 No 1 ISSN:2302-1136 (2013).

[4] Nahampun, Maruli Tua. 2014. Sistem Pakar Diagnosa Penyakit Tanaman Kelapa Sawit dengan Metode Dempster-Shafer. Jurnal Pelita Informatika Budi Darma Vol. VII. ISSN : 2301-9425

[5] Henderi, Henderi, Junaidi Junaidi, and Tubagus Ahmad Harja Kusuma. "Dashboard Monitoring System Penjualan Dan Reward Mobile Kios PT. Telekomunikasi Seluler." Semantik 2.1 (2012).

[6] Minarni, dan Rahmad Hidayat. 2013. "Rancang Bangun Aplikasi Sistem Pakar Untuk Kerusakan Komputer Dengan Metode Backward Chaining". Padang: Institut Teknologi Padang. Vol 1 No 1. April 2013

[7] Junaidi, Junaidi, Ridwan Arifin, and Amanda Septiani. "Rancang Bangun Aplikasi Sistem Inventory Berbasis Desktop Menggunakan JSE." Proceedings Konferensi Nasional Sistem dan Informatika (KNS\&I) (2015).

[8] Abdul Sani Sembiring. 2013. Sistem Pakar Diagnosa Penyakit Dan Hama Tanaman Padi. Medan: STMIKBudi Darma. Vol 3. Maret 2013.

[9] Junaidi, Junaidi, Novi Cholisoh, and Nur Hasanah. "Rancang Bangun Sistem Manajemen Aset IT Untuk Pencatatan History Maintenance Sebagai Pendukung Keputusan." SENSI Journal 4.2 (2018): 220-231.

[10] Prabowo, dkk. 2013. Sistem Pakar untuk Mendiagnosa dan Menanggulangi Penyakit pada Ikan Lele Dumbo(Clarias Gariepinus) Menggunakan Metode Backward Chaining. Jurnal Simposium Nasional Teknologi Terapan(SNTT). ISSN : 2339-028X

[11] Junaidi, Junaidi, Retno Setianingsih, and Khusnul Khotimah. "Rancang Bangun Sistem Penerimaan Dan Pengeluaran Barang Menggunakan Java Aplikasi." Proceedings Konferensi Nasional Sistem dan Informatika (KNS\&I) (2015).

[12] Sentanu, Windy. 2013. Sistem Pakar untuk Mendiagnosa Gangguan LAN. Skripsi. Tangerang : STMIK Raharja

[13] Junaidi, Junaidi, Sugeng Santoso, and Lusyani Sunarya. "Rekayasa Teknik Pemrograman Pencegahan Dan Perlindungan Dari Virus Lokal Menggunakan API Visual Basic." CCIT Journal 1.2 (2008): 134-153.

[14] Rizaldi, Adrian. 2014. "Sistem Pakar Identifikasi Karakter Siswa dalam Menentukan Konsentrasi Belajar dengan Metode Forward Chaining pada SMA Yuppentek 1 Kota Tangerang". Skripsi. Tangerang : STMIK Raharja 
ISSN : $2356-5195$

[15] Junaidi, Junaidi, Abdul Roji, and Kharis Munawar. "Konsep Otomatisasi Sistem Pembayaran SPP Online Untuk Mengurangi Tingkat Keterlambatan." Proceedings Konferensi Nasional Sistem dan Informatika (KNS\&I) (2015).

[16] Lucy, Bunda. 2016. Panduan Praktis Tes Minat \& Bakat Anak. Jakarta: Penebar Plus+ (Penebar Swadaya Grup), DePorter, B \& Hernacki. M. (2015). Quantum Learning. Bandung : Kaifa 